\title{
Implementing a template for major incident reporting: experiences from the first year
}

\author{
Sabina Fattah ${ }^{1,2^{*}}$, Marius Rehn $n^{1,3,4}$ and Torben Wisborg ${ }^{2,5,6}$
}

\begin{abstract}
Major incidents are resource-demanding situations that require urgent and effective medical management. The possibility to extract learning from them is therefore important. Comparative analysis of information based on uniform data collection from previous incidents may facilitate learning. The Major Incident Reporting Collaborators have developed a template for reporting of the medical pre-hospital response to major incidents. The template is accompanied by an open access webpage (www.majorincidentreporting.org) for online reporting and access to published reports. This commentary presents the experiences from the first year of implementing the template including a presentation of the five published reports.
\end{abstract}

Keywords: Major incident, Reporting, Lessons learned

\section{Background}

Major incidents are resource-demanding situations that require urgent and effective medical management. The available epidemiological data is heterogeneous and sparse, and thus of little help as a resource for planners. Major incidents comprise situations such as natural disasters, road traffic accidents, terrorist attacks and other causes of major trauma and medical morbidity. Given the unambiguity of major incident definitions [1, 2] (c.f Fig. 1) epidemiological data remains heterogeneous and no true incidence is described. A recent commentary asks "Why are we not learning from major incidents?" [3]. Comparative analysis of information based on uniform data collection from previous incidents may facilitate learning.

Several data templates with the aim of collecting uniform data from major incidents have been published [4]. In the absence of a feasibility-tested template especially focused on pre-hospital response, The Major Incident Reporting Collaborators developed a template for reporting of the medical pre-hospital response to major incidents [2]. The template is accompanied by an open access webpage (www.majorincidentreporting.org) for online reporting and access to published reports.

\footnotetext{
* Correspondence: sabina.fattah@norskluftambulanse.no

${ }^{1}$ Department of Research and Development, Norwegian Air Ambulance

Foundation, Drøbak, Norway

${ }^{2}$ Anaesthesia and Critical Care Research Group, Faculty of Health Sciences,

University of Tromsø, Tromsø, Norway

Full list of author information is available at the end of the article
}

The aims of majorincidentreporting.org:

- To be a global open access online solution for both reporting and accessing reports describing the prehospital medical response to major incidents.

- Contribute to learning from previous incidents by comparative analysis of uniform data.

- Use such information to be better prepared and respond to the next incident in a more evidencebased manner.

What makes the template different from the preexisting ones?

- Open access online reporting is available.

- All reports can be easily accessed at one location.

- Preliminary qualitative feasibility testing of the template has been undertaken.

\section{Confidentiality and data ownership}

It was necessary to develop legal disclaimers for both the reporters and readers of reports, as the goal is global reporting with every country having its own legal situation. Before accessing the online reports readers must accept the terms and conditions stating that the authors are responsible for their content.

Patient confidentiality is especially sensitive in highly profiled cases with few patients involved and where 


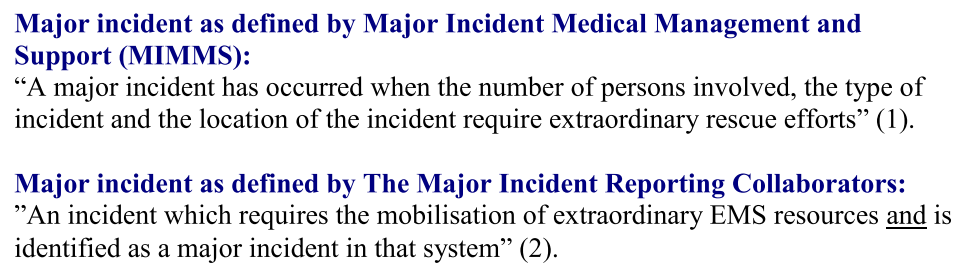

"A major incident has occurred when the number of persons involved, the type of incident and the location of the incident require extraordinary rescue efforts" (1).

Major incident as defined by The Major Incident Reporting Collaborators:

"An incident which requires the mobilisation of extraordinary EMS resources and is identified as a major incident in that system" (2).

Fig. 1 Definitions of major incidents

patient information is available in the public domain through media and official reports. Due to the management of the webpage currently being situated in Norway, and lack of internationally applicable laws on this field, the Norwegian Data Protection Authority was consulted. Their decision was that data on less than six persons should not be presented. This limitation regarding patient data has been implemented into the online template. To further ensure confidentiality the editorial board revises information in each report that could compromise patient confidentiality prior to publication.

\section{Presentation}

Limited financial resources have been a challenge as the webpage is solely sponsored by a charity (the Norwegian Air Ambulance Foundation). The reports are accompanied by a map of the affected area to make orientation easier for those unfamiliar with the region and data is presented in the format of questions accompanied by the corresponding answer. Limitations exist with regard to making the reports suitable for journal publication without extensive revisions. However, using the systematic information in the online template as a framework for case report structure is emphasized, and the subsequent publication of a case report after submitting data through the template and website is encouraged.

\section{Future implementation}

Both wider implementation and more secure funding are necessary for the further dissemination of the template and expand the existing technological solutions and manpower for maintaining the project. Anchoring the project under national health authorities is a main goal, as is the involvement of authorities responsible for other emergency responders such as police and fire services. The template is limited to primarily the prehospital medical response in a sudden-onset emergency. Development of sub-templates for reporting a small amount of data especially relevant for Helicopter Emergency Medical Services (HEMS), chemical, biological, radiological and nuclear (CBRN), police and fire response among others may be a possibility for making the template useful in a wider context.

\section{Challenges in dissemination}

The main challenge so far has been the time delay in receiving completed reports. Currently, five reports have been published (c.f Fig. 2, Table 1). Preliminary results from a qualitative feasibility study suggest a need for revision and reducing the volume of work necessary for completing a report (Fattah S, Agledahl KM, Rehn M, Wisborg T: Experience with a novel global open access template for major incidents: qualitative feasibility study. Submitted). Dissemination of published reports has been done through

\begin{tabular}{|c|c|c|}
\hline Incident title & Country & Report \\
\hline Utøya shootings & 믐을 Norway & HTML format $\hat{v} G$ \\
\hline Sheppey Crossing Bridge Road Traffic Accident & NAU & HTML format $\hat{v} G$ \\
\hline Prison Fire in Santiago de Chile & Chile & HTML format $\hat{v} G$ \\
\hline School shooting in Jokela & EFinland & HTML format $\hat{v} G$ \\
\hline Bus rollover in Skaidi & Hentway & HTML format $\hat{\imath}$ \\
\hline
\end{tabular}


Table 1 Overview of reports submitted to majorincidentreporting.org. All full-text reports are freely accessible in full-text at: http://www.majorincidentreporting.org/read.html\#.VRuiQ4tx2pp

\begin{tabular}{|c|c|c|c|}
\hline Reporter & Incident title & Summary & Example of a major lessons learned \\
\hline $\begin{array}{l}\text { Dr. Sollid } \\
\text { HEMS physician } \\
\text { Norway }\end{array}$ & Utøya shootings & $\begin{array}{l}\text { - } 21 \text { July } 2011 \\
\text { - Terrorist attack on youth at a political } \\
\text { summer camp on the Island of Utøya. }\end{array}$ & $\begin{array}{l}\text { - On-going shooting caused delayed } \\
\text { access to EMS. } \\
\text { Therefore need for a better system } \\
\text { for cooperating with police in incidents } \\
\text { with on-going shooting. }\end{array}$ \\
\hline $\begin{array}{l}\text { Dr. Hardy } \\
\text { A\&E doctor } \\
\text { United Kingdom }\end{array}$ & $\begin{array}{l}\text { Sheppey Crossing Bridge } \\
\text { Road Traffic Accident }\end{array}$ & $\begin{array}{l}\text { - } 5 \text { September } 2013 \\
\text { - Road traffic accident involving } 150 \text { cars and } 200 \text { people } \\
\text { occurred on the Sheppey Crossing Bridge in Kent. }\end{array}$ & $\begin{array}{l}\text { - Successful triage performed by highly } \\
\text { skilled paramedics } \\
\text { avoided unnecessary patients being } \\
\text { sent to hospital. }\end{array}$ \\
\hline $\begin{array}{l}\text { Dr. Cortes Picazo. } \\
\text { Director of EMS } \\
\text { Chile }\end{array}$ & $\begin{array}{l}\text { Prison Fire in Santiago de } \\
\text { Chile }\end{array}$ & $\begin{array}{l}\text { - } 8 \text { December } 2010 \\
\text { - Fire in Prison of San Miguel with } 1900 \text { inmates and guards } \\
\text { inside. } \\
\text { - Most of the victims died of inhalation } \\
\text { of smoke or toxic gases and burns. }\end{array}$ & - Avoid overcrowding in prisons. \\
\hline $\begin{array}{l}\text { Dr. Jama } \\
\text { Medical Director } \\
\text { of EMS } \\
\text { Finland }\end{array}$ & School shooting in Jokela & $\begin{array}{l}\text { - } 7 \text { November } 2011 \\
\text { - Student opened fire on school premises and killed eight } \\
\text { people. }\end{array}$ & $\begin{array}{l}\text { - Need for better communication } \\
\text { between EMS and police. EMS } \\
\text { was not allowed into the } \\
\text { building as the shooter was } \\
\text { still inside during the response phase. }\end{array}$ \\
\hline $\begin{array}{l}\text { Dr. Iversen } \\
\text { HEMS physician } \\
\text { Norway }\end{array}$ & Buss roll over in Skaidi & $\begin{array}{l}\text { - } 19 \text { November } 2011 \\
\text { - Buss carrying } 23 \text { persons rolled over in Skaidi; a cottage area } \\
\text { in mountainous inland of Finnmark } \\
\text { County. }\end{array}$ & $\begin{array}{l}\text { - As a strike of luck the first ambulance } \\
\text { on-scene had the same } \\
\text { triage system as the HEMS. Since the } \\
\text { time this incident occurred } \\
\text { a national standard for triage has } \\
\text { been implemented in Norway. }\end{array}$ \\
\hline
\end{tabular}

e-mails, twitter, facebook and commentaries [5], in addition to the website itself. As no formal obligation to report after major incidents exist, it should be underlined that it is considered a moral and ethical imperative to disseminate experiences and lessons learned after participating in major incidents, in the interest of future colleagues and victims. The template and website provides a mean for this.

\section{Future dissemination}

For future dissemination to succeed the template will need to be translated into several languages allowing it to be accessible to the global community who are non-fluent in English. Translation into Spanish is underway. Currently, the project has three endorsing societies; London's Air Ambulance, Norwegian National Advisory Unit on Trauma and the Norwegian Society for Trauma, Emergency and Disaster Medicine. A letter of support from the UK National Health Service (NHS) has been received and made available on www.majorincidentreporting.org. Endorsers do not offer financing, but help to spread the word of the template and its reporting possibilities. More endorsing societies are welcomed.

\section{Future research}

Questions for potential future research could include; How can the data in the reports be useful for others? Do different persons report similarly from the same incident?
What motivates people to report and how can we overcome hindrances in low rates of reporting? Is the template developed by European experts relevant for other settings? Comparison of response to and outcome of different incidents can also be a topic once more reports are received. The editorial board welcomes research initiatives seeking to use data from the database for non-profit research aimed at improving major incident preparedness and response.

\section{Conclusion}

Implementation and dissemination of the major incident reporting template depends on submission of reports, and is thus a challenge. Reports have been submitted and further work is underway to translate it into Spanish and find long-term financing for the project. The template and webpage are non-profit, freely accessible tools to facilitate learning lessons from major incidents. Therefore, we hope colleagues will support this work by helping to disseminate information of it, submit reports and collaborate on research projects related to it.

\section{Competing interests}

We declare no financial interests. SF and MR are members of the editorial board of www.majorincidentreporting.org and have solely an intellectual interest in disseminating information about it.

\section{Authors' contributions}

All authors contributed in the writing of the manuscript and approved its final version. 


\section{Acknowledgements}

We thank the persons who have kindly given of their time to submit reports and take part in the research involved in the implementation and follow-up of the template and webpage.

\section{Author details}

${ }^{1}$ Department of Research and Development, Norwegian Air Ambulance Foundation, Drøbak, Norway. ${ }^{2}$ Anaesthesia and Critical Care Research Group, Faculty of Health Sciences, University of Tromsø, Tromsø, Norway. ${ }^{3}$ Field of Pre-hospital Critical Care, Network of Medical Sciences, University of Stavanger, Stavanger, Norway. ${ }^{4}$ London's Air Ambulance, The Helipad, Royal London Hospital, Whitechapel, London, UK. ${ }^{5}$ Department of Anaesthesiology and Intensive Care, Hammerfest Hospital, Finnmark Health Trust, Hammerfest, Norway. ${ }^{6}$ Norwegian National Advisory Unit on Trauma, Oslo University Hospital, Oslo, Norway.

Received: 4 May 2015 Accepted: 17 June 2015

Published online: 05 August 2015

\section{References}

1. Advanced Life Support Group. Major Incident Medical Management and Support, the Practical Approach at the scene. Plymouth: BMJ Publishing Group; 2002.

2. Fattah S, Rehn M, Lockey D, Thompson J, Lossius HM, Wisborg T, et al. A consensus based template for reporting of pre-hospital major incident medical management. Scand J Trauma Resusc Emerg Med. 2014;22:5.

3. Hardy S. Major incidents in England. BMJ. 2015;350:h1712.

4. Fattah S, Rehn M, Reierth E, Wisborg T. Systematic literature review of templates for reporting prehospital major incident medical management. BMJ Open. 2013;3:e002658.

5. Fattah S, Rehn M, Wisborg T. A novel template for reporting pre-hospital major incident medical management. Acta Anaesthesiol Scand. 2014;58:1161-2

\section{Submit your next manuscript to BioMed Central and take full advantage of:}

- Convenient online submission

- Thorough peer review

- No space constraints or color figure charges

- Immediate publication on acceptance

- Inclusion in PubMed, CAS, Scopus and Google Scholar

- Research which is freely available for redistribution 